\title{
Komunikasi Pemasaran Viral Marketing (Studi Kasus Kopi Kwang Koan)
}

\author{
Yenty Boentoro, Sinta Paramita \\ Yentyboen@gmail.com,Sintap@fikom.untar.ac.id \\ Fakultas Ilmu Komunikasi Universitas Tarumanagara
}

\begin{abstract}
Development of communication technology is growing very rapidly especially social media.Social Media can be a new medium for business people to conduct marketing communication.In addition to the relatively cheaper advertising costs, social media can reach a wider audience.This research examines the marketing communication of Viral Marketing in creating a business brand awareness of SMES case studies Coffee Kwang Koan.The purpose of this research is to know the influence of digital word of mouth or exposure that influencers do on Instagram social media in creating brand awareness and its effect on the development of the general business. The research object consists of two ethnic coffee shops, Kedai Kwang Koan.This study used a descriptive qualitative method by conducting interviews with Johny Poluan as the owner as the main speaker and observing the visitors of the Kwang Koan coffee shop.
\end{abstract}

Keywords: marketing communication, kwang koan coffee, viral marketing, word of mouth.

\begin{abstract}
Abstrak
Perkembangan teknologi komunikasi berkembang sangat pesat khususnya media sosial. Media sosial dapat menjadi medium baru bagi pelaku bisnis untuk melakukan komunikasi pemasaran. Selain biaya iklan yang relatif lebih murah, sosial media dapat menjangkau khalayak yang lebih luas. Penelitian ini mengkaji tentang komunikasi pemasaran Viral Marketing dalam menciptakan brand awareness bisnis UMKM studi kasus Kopi Kwang Koan. Tujuan penelitian ini untuk mengetahui pengaruh word of mouth digital atau exposure yang dilakukan influencer di media sosial instagram dalam menciptakan brand awareness dan efeknya terhadap perkembangan bisnis secara umum. Objek penelitian terdiri dari dua kedai kopi etnis yakni Kedai Kwang Koan. Penelitian ini menggunakan metode kualitatif secara deskriptif yaitu dengan melakukan wawancara terhadap Johny Poluan selaku pemilik sebagai narasumber utama dan melakukan pengamatan terhadap pengunjung Kedai Kopi Kwang Koan.
\end{abstract}

Kata Kunci: komunikasi pemasaran, kopi kwang koan, viral marketing, word of mouth.

\section{Pendahuluan}

Perkembangan teknologi komunikasi berkembang sangat pesat khususnya media sosial sehingga setiap orang dapat mengakses akun sosial media seperti instagram, facebook, twitter, dan sebagainya. Akses internet kini menjadi sebuah kebutuhan dalam mendapatkan informasi, hiburan, pendidikan, kebutuhan hidup sehari-hari bahkan dapat menjadi sumber mata pencaharian bagi jutaan penjual online. Perubahan-perubahan yang terjadi dalam masyarakat, terutama karena perkembangan teknologi komunikasi (baca digital), telah membawa perubahan besar pada pola kehidupan masyarakat, mulai dari pola berkomunikasi, pola berinteraksi, sampai pola menentukan pembelian (Sukendro dan Pandrianto, 2019). 
Media sosial menjadi medium baru bagi pelaku bisnis untuk melakukan komunikasi pemasaran. selain biaya iklan yang relatif lebih murah, sosial media dapat menjangkau khalayak yang lebih luas. Era komunikasi digital seperti saat ini memberikan pengaruh cukup besar pada dunia komunikasi pemasaran. Komunikasi pemasaran memungkinkan perusahaan menghubungkan merek dengan orang, tempat acara, pengalaman dan hal lainya. Komunikasi pemasaran harus diintegrasikan untuk menghantarkan pesan yang konsisten dan mencapai positioning yang strategis (Kotler, 2009).

Strategi pemasaran digunakan untuk memperkenalkan merek kepada masyarakat yang dapat dilakukan menggunakan teknik marketing Influencer. Influencer adalah orang yang memiliki audiens yang banyak di sosial media sehingga mempunyai kemampuan untuk memberikan pengaruh yang kuat menciptakan persepsi followers terhadap suatu produk. Volume followers sosial media seorang influencer dapat berkisar dari ratusan ribu, jutaan, hingga milyaran. Semakin banyak pengikut semakin besar peluang bagi pelaku usaha untuk mendapatkan calon pembeli. Marketing Influencer menghasilkan tagar yang merupakan formasi dari word of mouth digital yakni komunikasi dari mulut ke mulut berupa pemberian rekomendasi secara individu atas suatu produk atau jasa. Hal ini bertujuan untuk memberikan informasi di media sosial.

Maraknya Industri Kedai Kopi di Indonesia membuat persaingan antar merek berlomba untuk mendapatkan posisi di pasar. Banyak bermunculan kedai kopi modern yang menawarkan berbagai konsep yang menarik dan unik. Setiap kedai kopi memiliki kategori dan target pasar nya tersendiri, sehingga walaupun terdapat banyak persaingan dalam industri ini masih memiliki potensi bisnis yang besar untuk masa yang akan datang. Sebab kopi sudah menjadi gaya hidup yang sudah menyebar ke segala lapisan usia status sosial, dan gender.

Kopi Kwang Koan adalah salah satu kopitiam di Jakarta yang menawarkan konsep kedai kopi etnik tradisional. Kopitiam berasal dari gabungan kata Kopi dari bahasa Melayu dan kata "Tiam” yang berarti kedai dalam bahasa Hokkien. Selain Kopi Joni terdapat kedai kopi yang memiliki konsep yang hampir sama, yakni Kopi Tak Kie. Keduanya merupakan kedai kopi etnik, namun popularitas Kopi Joni lebih menonjol semenjak viral di sosial media instagram dan munculnya hashtag \#SALAMKOPIJONI. Salam kopi Joni ini dipopulerkan oleh salah satu akun yang berpengaruh di instagram dan seketika menjadi trending topic.

\section{Komunikasi Pemasaran}

Komunikasi pemasaran digunakan untuk menginformasikan tentang produk dan merek yang dijual secara langsung maupun tidak langsung. Pemasaran merupakan strategi perencanaan pelaku usaha dalam mengkomunikasikan merek kepada khalayak. Komunikasi pemasaran memungkinkan perusahaan menghubungkan merek dengan orang, tempat acara, pengalaman dan hal lainya. Komunikasi pemasaran harus diintegrasikan untuk menghantarkan pesan yang konsisten dan mencapai positioning yang strategis (Kotler, 2009).

\section{Marketing Mix}

"Marketing mix is the set of tactical marketing tools that the firm blends to produce the response it wants in the target market" (Kotler dan Armstrong, 2012). 
"Bauran pemasaran adalah Kesalahan pemasaran adalah seperangkat alat pemasaran taktis yang dipadukan perusahaan untuk menghasilkan respons yang diinginkan di pasar sasaran".

\section{Elemen Integrated MarKeting Communications terdiri dari:}

\section{a. Periklanan}

Iklan merupakan bentuk komunikasi untuk menyampaikan informasi mengenai produk atau jasa tertentu. Biaya iklan bervariatif tergantung pada medium yang digunakan dan tampilan iklan yang diinginkan pelaku bisnis. Sebuah iklan tidak hanya berguna sebatas pada menginformasikan produk atau jasa perusahaan, namun juga berperan dalam mengingatkan, membedakan, dan mempengaruhi pelanggan maupun calon konsumen akan produk atau jasa suatu perusahaan (Fill, 1999). Melalui iklan, pelaku bisnis dapat menciptakan kesadaran pada merek dan mempengaruhi sikap pelanggan.

b. Promosi penjualan

Sales promotion terdiri dari semua kegiatan pemasaran yang mencoba merangsang terjadinya aksi pembelian suatu produk yang cepat atau terjadinya pembelian dalam waktu yang singkat. Sales promotion merupakan cara promosi yang lebih menekankan pada kegiatan penjualan kepada sasaran, baik konsumen maupun distributor agar tercipta penjualan yang langsung dan peningkatan penjualan. Bentuk komunikasi pemasaran ini mempergunakan insentif sebagai kekuatan penjualan yang diharapkan mampu mempersuasi distributor ataupun konsumen agar melakukan pembelian sehingga terjadi penjualan sesegera mungkin. Bentuk sales promotion dapat meliputi kupon voucher, rabat, diskon, garansi dan sebagainya.

c. Penjualan personal

Dalam penjualan personal, perusahaan melakukan penjualan secara langsung atau tatap muka dengan calon pembeli. Tujuannya untuk memperkenalkan produk dan membentuk pemahaman mengenai produk atau jasa kepada calon pembeli, sehingga membuat mereka tertarik untuk mencoba dan akhirnya membeli.

d. Pemasaran interaktif

Pemasaran langsung dilakukan dengan berkomunikasi secara langsung dengan konsumen yang ditargetkan. Tujuannya untuk menghasilkan respon atau transaksi langsung dari calon pembeli. Respon yang dihasilkan bisa berupa inquiry, pembelian produk atau jasa, serta dukungan.

e. Hubungan masyarakat

Dengan adanya peran Humas sebagai salah satu alat dalam mengkomunikasikan dan memasarkan brand, maka kehadiran Humas ini tentunya menjadi hal yang penting terkait pembentukan dan pemeliharaan hubungan baik yang saling menguntungkan antara organisasi dengan publiknya. Humas yang memerankan fungsi manajemen ini merencanakan dan melaksanakan program aksi dalam rangka mendapatkan pemahaman dan penerimaan publik atas produk atau jasa yang ditawarkan oleh perusahaan.

\section{Viral Marketing}

Viral Marketing adalah suatu teknik pemasaran yang memanfaatkan sosial media untuk mencapai suatu tujuan pemasaran tertentu. Konsep kerjanya seperti perkembangbiakan virus, yaitu memperbanyak diri sendiri, membuat konsep ini disebut dengan Viral Marketing. Viral Marketing dapat berupa pemasaran dari mulut 
ke mulut (Word of Mouth Marketing) yang diperkuat dengan aktivitas pemasaran dan efek dari jaringan sosial.

Menurut Armstrong dan Kotler (2012) "viral marketing is the Internet version of word of mouth marketing, that involves creating an E-Mail message or other marketing event that is so infectious that customers will want to pass it along to their friend."

"Versi internetnya dari penggunaan mulut ke mulut, yang memiliki hubungan dengan menciptakan sebuah e-mail atau cara pemasaran yang sangat menular sehingga konsumen atau pelanggan bersedia atau mau untuk menyebarkan dan menyampaikannya kepada teman-teman mereka"

Konsep cara kerja dari viral marketing ini sendiri seperti layaknya sebuah penyebaran virus, yaitu memperbanyak dirinya sendiri. Seorang konsumen yang puas dengan suatu produk yang mereka beli atau jasa yang mereka dapatkan, secara otomatis akan menyebarluaskan informasi atau produk tersebut kepada kerabat mereka untuk juga mencoba dan membuktikannya sendiri. Pemasaran dari mulut ke mulut yang diperkuat dengan efek dari jaringan sosial atau media sosial juga termasuk dalam viral marketing (Kotler, 2009).

\section{Word Of Mouth}

Strategi pemasaran digunakan untuk memperkenalkan merek kepada masyarakat yang dapat dilakukan menggunakan teknik marketing Influencer. Influencer adalah orang yang memiliki audiens yang banyak di sosial media sehingga mempunyai kemampuan untuk memberikan pengaruh yang kuat menciptakan persepsi followers terhadap suatu produk. Volume followers sosial media seorang influencer dapat berkisar dari ratusan ribu, jutaan, hingga milyaran. Semakin banyak pengikut semakin besar peluang bagi pelaku usaha untuk mendapatkan calon pembeli. Marketing Influencer menghasilkan tagar yang merupakan formasi dari word of mouth digital yakni komunikasi dari mulut ke mulut berupa pemberian rekomendasi secara individu atas suatu produk atau jasa. Hal ini bertujuan untuk memberikan informasi di media sosial.

\section{Metode Penelitian}

Penelitian ini dilakukan dengan menggunakan metode studi kasus. Penulis melakukan riset atau analisis terhadap Kedai Kopi Kwang Koan untuk mendapatkan data. Perolehan data dilakukan dengan melakukan wawancara terhadap pemilik. Penelitian ini memanfaatkan buku bacaan yang berkaitan dengan penelitian. Penulis melakukan wawancara dengan teknik triangulasi untuk melakukan konfirmasi terhadap data yang diperoleh. Subjek dalam penelitian ini adalah bagaimana komunikasi pemasaran Viral marketing kedai kopi Kwang Koan. Sementara objek dalam penelitian ini adalah pengaruh Viral Marketing terhadap perkembangan bisnis kedai Kopi Kwang Koan secara umum.

\section{Hasil Penemuan dan Diskusi}

Setelah melakukan observasi dan wawancara selama kurang lebih 3 bulan. Penulis mendapatkan hasil penemuan bahwa :

1. Media sosial kini bisa menjadi medium untuk mengkomunikasikan brand. Hasilnya lebih efektif dari iklan cara konvensional yang diproduksi oleh perusahaan 
atau media besar dengan biaya yang relatif mahal. Hampir semua orang memiliki gadget juga memiliki akun sosial media seperti salah satunya instagram. Hal ini terjadi pada Kopi Kwang Koan yang viral akibat dari exposure yang dilakukan oleh seorang influencer yakni Hotman Paris Hutapea.

"Dalam melakukan pemasaran, Kopi Kwang Koan tidak menggunakan iklan berbayar di televisi atau di koran. Biayanya sangat mahal. Lagipula sekarang kita tinggal di zaman modern. Semua orang punya handphone untuk akses ke sosial media. Kopi Johny memiliki akun instagram namun harus dibedakan antara akun Kopi Joni yang pribadi dan franchise" (Hasil wawancara dengan Johny Poluan, pemilik Kopi Kwang Koan, jumat 25 Oktober 2019)

"Kopi Tak Kie tidak memiliki iklan dimanapun. Hanya sosial media yang dikelola oleh keponakan. Dalam umur yang segini saya menyerahkan hal itu kepada yang lebih muda" (Hasil wawancara dengan Latif Yulus, pemilik Kopi Tak Kie, Senin 28 Oktober 2019)

2. Exposure yang dilakukan oleh influencer membawa dampak bagi meningkatnya brand awareness Kopi Kwang Koan. Menurut penuturan pemilik Kopi Kwang Koan, nama Kopi Joni ini lebih populer karena mudah diucapkan dan merupakan nama populer yang diberikan oleh influencer pengacara fenomenal Hotman Paris Hutapea. Beliau menambahkan bahwa Kopi Joni terkenal dari Sumatera hingga Irian karena pelayanan hukum gratis yang diberikan oleh Hotman Paris Hutapea setiap minggu di Kopi Kwang Koan yang bertempat di jalan Kelapa Kopyor Kelapa Gading.

"Pengunjung Kedai Kopi Kwang Koan rata-rata dipenuhi oleh Hotman Paris Hutapea serta pengunjung yang datang untuk melihat idolanya pengacara terkenal (Hasil wawancara dengan Johny Poluan, pemilik Kopi Kwang Koan, jumat 25 Oktober 2019)”

3. Dampak dari komunikasi pemasaran digital berpengaruh besar terhadap perkembangan bisnis kopi Kwang Koan. Setelah viral di sosial media instagram pada tahun 2017, dalam jangka 2 tahun terdapat pertambahan cabang sebanyak 9 cabang yang terdiri dari 3 cabang dengan kepemilikan pribadi dan 6 cabang franchise.

"Semenjak viral 2 tahun lalu sekitar 2017 franchisenya bertambah menjadi 6 cabang dan kedai kopi milik pribadi bertambah 3 kedai dan akan bertambah di 2020 bahkan saya akan mengembangkan bistro kopi johny yang menunya akan selalu berubah (Hasil wawancara dengan Johny Poluan, pemilik Kopi Kwang Koan, jumat 25 Oktober 2019)"

4. Brand Image yang diciptakan dari fenomena viral Salam Kopi Johny di sosial media membuat Kopi Kwang Koan lebih dikenal dengan sebutan Kopi Johny sesuai dengan nama pemiliknya. Nama ini dipopulerkan oleh Hotman Paris Hutapea. Banyak masyarakat yang berasumsi bahwa Kopi Kwang Koan adalah kedai kopi milik Hotman Paris Hutapea karena sering disebutkan beliau dalam unggahan foto maupun videonya.

"Hubungan saya dengan pak Hotman sangat baik bahkan banyak yang berasumsi bahwa kopi Kwang Koan atau nama trendnya kopi Johny adalah milik Hotman Paris Hutapea (Hasil wawancara dengan Johny Poluan, pemilik Kopi Kwang Koan, jumat 25 Oktober 2019).” 


\section{Kesimpulan}

Kesimpulan yang dapat diambil dari penelitian ini adalah bahwa pada era komunikasi digital seperti saat ini, pelaku usaha dapat memanfaatkan medium media sosial untuk mengkomunikasikan mereknya karena terbukti lebih efektif. Strategi ini lebih efektif dan relatif murah dibandingkan dengan iklan konvensional yang diproduksi oleh perusahaan atau media besar. Semakin tinggi popularitas seorang influencer yang melakukan exposure brand, semakin tinggi peluang meningkatnya kesadaran akan suatu merek. Pelaku usaha dapat menggunakan strategi influencer marketing untuk meningkatkan traffic menggunakan sosial media engagement. Tidak ada yang lebih memahami brand dari perusahaan brand itu sendiri dan tidak ada yang lebih memahami audiens dari influencer itu sendiri. Sehingga dalam berkolaborasi dengan seorang influencer, pelaku usaha mendapatkan perspektif dari seorang yang lebih dekat dengan calon konsumennya. Pelaku usaha juga harus memiliki pikiran yang terbuka dalam melihat peluang bisnis. Salah satunya adalah berpartisipasi dalam menyediakan pembayaran e-payment. Transaksi pembayaran yang mudah dan promo dari transaksi yang dilakukan dapat menarik minat calon pembeli.

\section{Ucapan Terima Kasih}

Penulis mengucapkan terima kasih kepada seluruh narasumber, yaitu Bapak Johny Poluan selaku pemilik dari Kopi Kwang Koan dan Latif Yulus selaku pemilik Kopi Tak kie yang telah bersedia bekerja sama dan memberikan waktu dalam proses pengumpulan data penelitian ini. kemudian ucapan terima kasih juga diberikan kepada dosen pembimbing Fakultas Ilmu Komunikasi Universitas Tarumanagara yang telah memberikan bimbingan dan arahan atas terselesaikannya penelitian ini. Terakhir kepada seluruh rekan-rekan diskusi di Fakultas Ilmu Komunikasi Universitas Tarumanagara.

\section{Daftar Pustaka}

Cutlip, Scott M.,dkk.. (2006). Effective Public Relations, Jakarta: Prenada Media Group

Fill, Chris. (1999). Marketing Communications: Contexts, Contents and Strategies. Cornell University : Prentice Hall

Hasan. (2010). Marketing. Yogyakarta : Media Pressindo

Kartajaya, Hermawan. (2007). Memenangkan Persaingan Dengan Segitiga Positioning, Diferensiasi Dan Brand, Bandung: Mizan Pustaka.

Kotler, Philip. (2007). Manajemen Pemasaran. Jakarta : PT.Indeks

Kotler, K. (2009). Manajemen Pemasaran 1. Jakarta: Erlangga

Kotler, Philip and Gary Armstrong. (2012). Prinsip-prinsip Pemasaran. Jakarta: Erlangga

Kotler dan Keller. (2012). Manajemen Pemasaran. Edisi 12. Jakarta: Erlangga.

Sukendro, Gregorius Genep \& Pandrianto, Nigar. (2019). Diagnosa Komunikasi Brand Activation Dan Media Digital Atas Eksistensi Brand Studio Rekaman Lokananta. Jurnal Komunikasi.

Widya Harsana, James Indra Winawan. (2009). Pemasaran Hemat Penjualan Berlipat Melalui Creative Viral Marketing. 